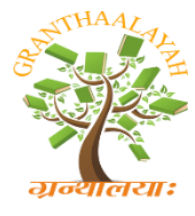

\author{
INTERNATIONAL JOURNAL OF RESEARCH - \\ GRANTHAALAYAH \\ A knowledge Repository
}

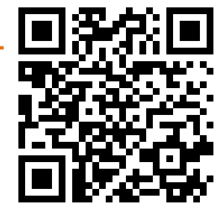

Social

\title{
QUALITY STUDENT SERVICES DELIVERY FOR MINDORO AND MARINDUQUE STATE COLLEGES
}

\author{
Evelyn A. Leynes ${ }^{* 1}$ \\ ${ }^{* 1}$ Mindoro State College of Agriculture and Technology, Main Campus, Alcate, Victoria, \\ Oriental Mindoro (Philippines)
}

\begin{abstract}
This study looked into the profile of the program implementers in terms of age, sex, and educational attainment, number of years as service practitioners and trainings and seminars attended. Likewise it also covered the assessment on the different institutional programs and services which include admission services, guidance and counseling services, scholarship and financial assistance, food services, health services, library services and student housing. The integration of innovative practices in the delivery of quality student services were also determined. Research design was descriptive with the questionnaire as the main data gathering instrument complemented by interview and focus group discussion. Respondents of the study were 84 program implementers and 331 student leaders in the three state colleges in Mindoro and Marinduque (MIMA) provinces including their satellite campuses. Profile description of the program implementers revealed majority were female, middle -aged between 25-35 years of age, masteral degree holders with at most ten years in service as student service implementers. Attended trainings were relatively few. Further, the program implementers assessed the quality services delivery for admission, guidance and counselling services, scholarship and financial assistance were delivered to a great extent while health, food and library services were rated moderate extent. Housing services were delivered to a slight extent. On the other hand, student leaders rated the quality services delivery of all areas was to a moderate extent. Significant differences in the assessments between program implementers and student leaders were noted in most areas except for student housing services where both concurred delivery to a slight extent. More so, the innovative practices to achieve quality student service delivery were delivered to a moderate extent. Based on the findings, a management plan for quality student service delivery for Mindoro and Marinduque state colleges was prepared. It was recommended that the management plan be reviewed for enhancement and tried for implementation to achieve quality student service delivery.
\end{abstract}

Keywords: Student Welfare Services; Institutional Program and Services Innovative Practices; Management Plan.

Cite This Article: Evelyn A. Leynes. (2019). "QUALITY STUDENT SERVICES DELIVERY FOR MINDORO AND MARINDUQUE STATE COLLEGES." International Journal of Research - Granthaalayah, 7(6), 93-106. https://doi.org/10.29121/granthaalayah.v7.i6.2019.763. 


\section{Introduction}

All higher education institutions (HEIs) have the responsibility to work on the development and growth of the students to prepare them for the world of work and make them well- equipped, value laden, productive future citizens of the country. Thus, HEIs must see to it that the experiences they provide are student-centered and responsive to their needs and the world at large. In the school setting, the specific task of helping and assuring that students are served, shaped and helped in their development is through student services program. Academic support services such as student welfare services and institutional student programs and services are offered by each learning institution so as to ensure that basic services necessary to serve and develop the well-being of students and programs and activities offered by the HEIs to facilitate the delivery of essential services to the students guarantee their inclusive development.

The Commission on Higher Education provides minimum standards to HEIs to improve the quality of student affairs services programs to promote access to quality, relevant, efficient and effective student affairs and services; support student development and welfare and ensure that all HEIs comply with the minimum requirements for student affairs and services. This pressures those who manage the student affairs unit as they are tasked to guarantee that there is effective implementation of all the student services programs that offer optimum growth and wider learning opportunities outside the classroom. Though, state colleges are experiencing budget-cuts, they need to equate with universities to avoid compromising quality services for the students. MIMAROPA, for instance, is composed of island provinces but the SUCs have to provide equivocally the same services as those in the urban areas. Thus it is needed to identify the services each of the SUC offers to the students. That majority of students are those coming from underprivileged families who cannot afford education in private HEIs or even SUCs in the cities does not exclude them in receiving quality service. Moreover, students, being the core of instruction should be provided quality services since, satisfaction is seen as an important aspect of recruitment and retention. Therefore, to define what has to be done to maintain a highly functional and responsive student services programs, assessment is necessary to identify the strengths and weaknesses of each SUC in terms of student services offered. Careful evaluation of the existing ones and proposing a management plan are deemed relevant.

Since every institution has unique capabilities, needs and resources, aforementioned student services and quality and status of implementation vary as in the case of state colleges in the Mindoro and Marinduque provinces. As state run colleges, the Mindoro State College of Agriculture and Technology (MinSCAT), Occidental Mindoro State College (OMSC) and Marinduque State College (MSC) strictly adhere to the rules and regulations promulgated by the Commission on Higher Education and accrediting bodies as part of the quality assurance of its academic programs. This does not guarantee however, that student services in the aforementioned colleges are not beset by challenges, issues and limitations. With the limited resources of the student affairs unit from the fiduciary funds of the colleges, their operation and management largely depend on the organizational structure, available resources and facilities, creativity, resourcefulness, cooperation, training and commitment of student services implementers.

Moreover, the call for internationalization in the higher education institutions in the country to enhance institutional competitiveness created opportunities for inbound mobility among international students. Student services providers are now faced of the challenges of 
accommodating each student unique cultural background and needs. Higher education serves diverse groups of students who are disabled; international students; students of different sexual orientations; and so forth. These groups have different needs that should be attended to by student affairs and services as they play a pivotal role in addressing these issues thus, the need for a comprehensive support system of academic and student services that should complement each other is imperative. The researcher, being one of the program implementers has strong desire to create efficient student services that are focused on the necessities, in order to provide the required support for academic activity and stimulate personal, social, cultural and cognitive development of students. With this, the researcher advocates on a continuous evaluation/ assessment to strengthen the implementation of each program and the strong support of the administration and program implementers to the proposed management plan to enhance the quality student service delivery for Mindoro and Marinduque State Colleges for the benefit of their primary clients, the students.

\section{Materials and Methods}

The study aimed to assess the quality of student services delivery of the student affairs services in the three state colleges in Mindoro and Marinduque provinces. Specifically, it determine the profile of the program implementers with reference to age, sex, educational attainment, number of years as service practitioner and number of seminars/ training attended focusing on the following concerns, assess the extent of implementation of student welfare and institutional student program services and determine significant differences in the assessments of the two groups of respondents. It also delved on the innovative practices in student services delivery that may be integrated.

A descriptive research design was used with the survey questionnaire main data gathering instruments. Interview and focus group discussion were also complemented to substantiate the data gathered the first group of respondents were the 84 program implementers of different student services and the second group were the 317, student leaders of the Mindoro and Marinduque State Colleges including its satellite campuses. Ranking, weighted mean and t- test were used in the data analysis.

\section{Results and Discussions}

\subsection{Profile of Program Implementers}

Table 1: Profile of the Program Implementers as to Age

\begin{tabular}{|c|l|l|}
\hline Age & Frequency & Percentage \\
\hline Above 50 years old & 16 & 19 \\
$45-50$ years old & 13 & 15 \\
$35-45$ years old & 22 & 26 \\
$25-35$ years old & 28 & 33 \\
25 years old and below & 5 & 6 \\
\hline Total & 84 & 100 \\
\hline
\end{tabular}




\subsubsection{Profile of the Program Implementers}

Twenty eight (28) or 33.33 percent of the program implementers belonged to the age range of 2534 years old which was the highest frequency in the age distribution. Only five (5) or 6 percent of them were on the age bracket of below 25 years old.

Table 2. Profile of Program Implementers as Sex

\begin{tabular}{|c|c|c|}
\hline Sex & Frequency & Percentage \\
\hline Male & 20 & 24 \\
\hline Female & 64 & 76 \\
\hline Total & 84 & 100 \\
\hline
\end{tabular}

\subsubsection{Profile of Program Implementers as Sex}

Majority of the program implementers were female which constituted 64 or 76 percent while 24 percent were male.

Table 3: Profile of the Program Implementers as to Educational Attainment

\begin{tabular}{|l|c|c|}
\hline Educational Attainment & Frequency & Percentage \\
\hline Doctorate Degree Graduate & 10 & 12 \\
With units in Ph.D/Ed.D & 13 & 15 \\
Master's Degree Graduate & 28 & 33 \\
With units in Masteral & 13 & 16 \\
Bachelor's Degree Graduate & 20 & 24 \\
\cline { 2 - 3 } Total & 84 & 100 \\
\hline
\end{tabular}

\subsubsection{Profile of the Program Implementers as to Educational Attainment}

Majority of the program implementers with 28 or 33.33 percent had a Masters' degree while 20 or 24 percent of them was Bachelor's degree, with units in Ph.D. / Ed. D. and Masteral got the same frequency of thirteen (13) or 15 percent, and with a Doctorate degree graduate had the lowest frequency of ten (10) or 12 percent.

Table 4: Profile of Program Implementers as to the Number of Years as Service Practitioner

\begin{tabular}{|l|l|l|}
\hline No. of years as Service Practitioner & Frequency & Percentage \\
\hline Above 20 years & 9 & 11 \\
$16-20$ years & 5 & 6 \\
$11-15$ years & 16 & 19 \\
$5-10$ years & 27 & 32 \\
Below 5 years & 27 & 32 \\
\hline Total & 84 & 100 \\
\hline
\end{tabular}




\subsubsection{Profile of Program Implementers as to the Number of Years as Service Practitioner}

Most of the program implementers comprised of 27 or 32 percent were on the service 10 years and below, 11 to 15 years in service had obtained sixteen (16) or 19.05 percent followed by above 20 years with nine (9) or 11 percent. The least was 16 to 20 years in service has obtained five (5) or 6 percent.

Table 5: Profile if the Respondents as to the Number of Trainings Attended

\begin{tabular}{|l|l|l|}
\hline No. of Seminars and Training Attended & Frequency & Percentage \\
\hline 5 and below per year & 54 & 64 \\
6 and above per year & 30 & 36 \\
\hline Total & 84 & 100 \\
\hline
\end{tabular}

\subsubsection{Profile if the Respondents as to the Number of Trainings Attended}

Fifty four (54) or 64 percent of the respondents had attended not more than seminars/trainings 5 and below per year while thirty (30) or 36 percent attended 6 and above per year.

\subsection{Assessment of Student Services}

Table 6: Assessment on Admission Services

\begin{tabular}{|c|c|c|c|c|}
\hline \multirow[t]{2}{*}{ Items } & \multicolumn{2}{|c|}{$\begin{array}{c}\text { Program } \\
\text { Implementers }\end{array}$} & \multicolumn{2}{|c|}{$\begin{array}{l}\text { Student } \\
\text { Leaders }\end{array}$} \\
\hline & WM & VI & WM & VI \\
\hline $\begin{array}{l}\text { 1. Conducts regular orientation to students and other } \\
\text { stakeholders regarding admission requirements, policies } \\
\text { and procedures }\end{array}$ & 3.68 & GE & 3.42 & $\mathrm{ME}$ \\
\hline $\begin{array}{l}\text { 2. Administers entrance examination to incoming } \\
\text { freshman students, walk-in and transferees }\end{array}$ & 3.71 & GE & 3.63 & GE \\
\hline 3. Inform the students on his/her examination results & 3.76 & GE & 3.43 & $\mathrm{ME}$ \\
\hline $\begin{array}{l}\text { 4. Releases notice of admission one week after the } \\
\text { entrance examination }\end{array}$ & 3.54 & GE & 3.28 & ME \\
\hline $\begin{array}{l}\text { 5. Posts admission requirements to the state college } \\
\text { website, bulletin boards for the information of everyone }\end{array}$ & 3.54 & GE & 3.25 & $\mathrm{ME}$ \\
\hline $\begin{array}{l}\text { 6. Distributes brochures and fliers containing the step by } \\
\text { step procedures and requirements for admission }\end{array}$ & 3.20 & $\mathrm{ME}$ & 3.18 & ME \\
\hline $\begin{array}{l}\text { 7. Ensures availability of application forms and other } \\
\text { admission paraphernalia }\end{array}$ & 3.54 & GE & 3.21 & $\mathrm{ME}$ \\
\hline $\begin{array}{l}\text { 8. Gives priority to persons with disabilities, pregnant } \\
\text { women and elderly }\end{array}$ & 3.63 & $\mathrm{GE}$ & 3.51 & GE \\
\hline $\begin{array}{l}\text { 9. Accepts and evaluates admission requirements based } \\
\text { on the policies, guidelines and standards of the state } \\
\text { college }\end{array}$ & 3.67 & GE & 3.39 & $\mathrm{ME}$ \\
\hline $\begin{array}{l}\text { 10. Accommodates and entertains inquiry of the students, } \\
\text { parents, transferees and walk - in }\end{array}$ & 3.77 & GE & 3.30 & $\mathrm{ME}$ \\
\hline
\end{tabular}


DOI: 10.5281/zenodo.3262197

\begin{tabular}{|l|l|l|l|l|}
\hline $\begin{array}{l}\text { 11. Provides spacious, conducive and well ventilated } \\
\text { examination rooms for the Students }\end{array}$ & 3.39 & GE & 3.17 & ME \\
\hline $\begin{array}{l}\text { 12. Respond to inquiries of the students, parents and walk- } \\
\text { in clients with courtesy and respect }\end{array}$ & 3.72 & GE & 3.30 & $\mathrm{ME}$ \\
\hline $\begin{array}{l}\text { 13. Provides waiting area for the convenience of parents } \\
\text { and students }\end{array}$ & 3.58 & GE & 3.17 & $\mathrm{ME}$ \\
\hline 14. Observes NO noon break policy & 3.30 & ME & 2.87 & $\mathrm{ME}$ \\
\hline $\begin{array}{l}\text { 15. Provides well- defined policies and procedure on the } \\
\text { selection and admission of students }\end{array}$ & 3.58 & GE & 3.19 & $\mathrm{ME}$ \\
\hline Composite Mean & $\mathbf{3 . 5 7}$ & GE & $\mathbf{3 . 2 9}$ & ME \\
\hline
\end{tabular}

\subsubsection{Admission Services}

As assessed by the program implementers and student leaders, the conduct of entrance examination to incoming freshman students, walk-in and transferees was administered to a great extent affirmed in weighted means of 3.71 and 3.63; lowest weighted mean was 3.20 on that brochures and fliers containing step by step procedures and requirements for admission were distributed. Summary of the assessments of program implementers on admission services indicated a composite mean of 3.57 , described as performed to a great extent.

Student leaders assessed observance of No noon break policy obtained was followed to a moderate extent and given lowest weighted mean of 2.87. The composite mean of 3.29 showed that the student leaders assessed most of the admission services were administered to a moderate extent.

Table 7: Assessment on Guidance and Counseling Services

\begin{tabular}{|l|l|l|l|l|}
\hline Items & \multicolumn{2}{|c|}{$\begin{array}{c}\text { Program } \\
\text { Implementers }\end{array}$} & \multicolumn{2}{c|}{$\begin{array}{c}\text { Student } \\
\text { Leaders }\end{array}$} \\
\cline { 2 - 5 } & WM & \multicolumn{1}{|c|}{ VI } & VI \\
\hline $\begin{array}{l}\text { 1. Plans and implements guidance and counseling } \\
\text { programs and activities }\end{array}$ & 3.69 & GE & 3.37 & ME \\
\hline $\begin{array}{l}\text { 2. Ensures the confidentiality of the client's information, } \\
\text { profile, and condition }\end{array}$ & 3.73 & GE & 3.36 & ME \\
\hline $\begin{array}{l}\text { 3. Conducts seminars and intervention programs and } \\
\text { strategies to address issues like bullying, teenage } \\
\text { pregnancy, drop-out and the like }\end{array}$ & & SE & 2.00 & SE \\
\hline $\begin{array}{l}\text { 4. Provides guidance and assistance to students on how to } \\
\text { survive and adjust with college life }\end{array}$ & 3.55 & GE & 3.2 & ME \\
\hline $\begin{array}{l}\text { 5. Provides equal rights and activities to students in } \\
\text { general }\end{array}$ & 3.61 & GE & 3.23 & ME \\
\hline 6. Conducts individual and group counselling & 3.43 & ME & 3.14 & ME \\
\hline $\begin{array}{l}\text { 7. Conducts research studies on the needs, problems and } \\
\text { difficulties encountered by the students to improve its } \\
\text { services }\end{array}$ & 3.17 & ME & 3.24 & ME \\
\hline 8. Conducts career and occupational orientation program & 3.48 & ME & 3.25 & ME \\
\hline 9. Organizes peer facilitators & 3.38 & ME & 3.15 & ME \\
\hline
\end{tabular}


DOI: 10.5281/zenodo.3262197

\begin{tabular}{|l|l|l|l|l|}
\hline $\begin{array}{l}\text { 10. Conducts follow-up and monitoring system to ensure } \\
\text { the well-being of the Students }\end{array}$ & 3.39 & $\mathrm{ME}$ & 3.19 & $\mathrm{ME}$ \\
\hline $\begin{array}{l}\text { 11. Conducts activities to reduce the anxiety, depression, } \\
\text { and stress of the Students }\end{array}$ & 2.06 & $\mathrm{SE}$ & 2.50 & $\mathrm{ME}$ \\
\hline $\begin{array}{l}\text { 12. Organize activities that improve students self- } \\
\text { awareness, self-understanding and decision making }\end{array}$ & 2.72 & $\mathrm{ME}$ & 2.22 & $\mathrm{SE}$ \\
\hline $\begin{array}{l}\text { 13. Conducts personality development seminar to boost } \\
\text { self-confidence of the students }\end{array}$ & 3.31 & $\mathrm{ME}$ & 3.18 & $\mathrm{ME}$ \\
\hline $\begin{array}{l}\text { 14. Implements intervention measures and follow-up to } \\
\text { students' absenteeism and habitual tardiness }\end{array}$ & 2.15 & $\mathrm{ME}$ & 3.13 & $\mathrm{ME}$ \\
\hline $\begin{array}{l}\text { 15. Accepts referrals from students, teachers and other } \\
\text { stakeholders }\end{array}$ & 3.56 & $\mathrm{GE}$ & 3.21 & $\mathrm{ME}$ \\
\hline 16. Conducts exit interviews for the graduating students & 3.56 & $\mathrm{GE}$ & 3.26 & $\mathrm{ME}$ \\
\hline $\begin{array}{l}\text { 17. Provides life skills training for students like conflict, } \\
\text { stress and time management, harassment and other student } \\
\text { development activities }\end{array}$ & 2.43 & $\mathrm{SE}$ & 2.50 & $\mathrm{ME}$ \\
\hline Composite Mean & $\mathbf{3 . 6}$ & GE & $\mathbf{3 . 2 9}$ & $\mathrm{ME}$ \\
\hline
\end{tabular}

\subsubsection{Guidance and Counseling Services}

The program implementers assessed that the guidance office ensures the confidentiality of the client's information, profile and condition to a great extent which obtained a weighted mean of 3.73. On the other hand, the conduct of seminars and intervention programs and strategies to address bullying, teenage pregnancy, drop-out and the like was addressed to a slight extent evidenced by lowest weighted mean of 2.04. For program implementers, guidance services delivery were to a moderate extent which yielded a composite mean of 3.06 .

On the other hand, student leaders' assessment of guidance services was perceived to a moderate extent which garnered the composite mean of 3.29. For the student leaders planning and implementation of guidance and counseling program of activities was extended to clienteles to a moderate extent reflected in highest mean value of 3.37. Student leaders concurred with program implementers on weak delivery programs on items that organize activity to improve student self awareness, self- understanding and decision making and another item which referred to the conduct of seminars and intervention programs and strategies to address bullying, teenage pregnancy, pregnancy, drop-out and the like which garnered the same lowest assessments shown in weighted means of 2.22 and 2.00 respectively.

Table 8: Assessment on Scholarship and Financial Assistance

\begin{tabular}{|l|l|l|l|l|}
\hline Items & \multicolumn{2}{|c|}{$\begin{array}{c}\text { Program } \\
\text { Implementers }\end{array}$} & \multicolumn{2}{|c|}{$\begin{array}{c}\text { Student } \\
\text { Leaders }\end{array}$} \\
\cline { 2 - 5 } & WM & VI & WM & VI \\
\hline $\begin{array}{l}\text { Provides free tuition and allowance to academic scholars, } \\
\text { athletes and performers }\end{array}$ & 3.71 & GE & 3.54 & GE \\
\hline $\begin{array}{l}\text { Prioritizes the poor but academically able students in } \\
\text { giving scholarships and financial assistance. }\end{array}$ & 3.71 & GE & 3.48 & ME \\
\hline
\end{tabular}


DOI: 10.5281/zenodo.3262197

\begin{tabular}{|l|l|l|l|l|}
\hline $\begin{array}{l}\text { Provides loans to financially incapable students with } \\
\text { minimal interest }\end{array}$ & 2.01 & SE & 2.34 & SE \\
\hline $\begin{array}{l}\text { Conducts regular meeting and consultation with the } \\
\text { scholars to discuss their problems encountered with their } \\
\text { scholarship grants }\end{array}$ & 2.49 & SE & 2.49 & SE \\
\hline $\begin{array}{l}\text { Monitors the academic performance of the scholars and } \\
\text { grantees periodically }\end{array}$ & 3.73 & $\mathrm{GE}$ & 3.46 & $\mathrm{ME}$ \\
\hline $\begin{array}{l}\text { Recommends academically able students to philanthropist } \\
\text { for scholarship and financial assistance }\end{array}$ & 3.57 & $\mathrm{GE}$ & 3.28 & $\mathrm{ME}$ \\
\hline $\begin{array}{l}\text { Enlightens the scholars and grantees on their duties, } \\
\text { responsibilities and benefits of the grants they are enjoying }\end{array}$ & 3.61 & $\mathrm{GE}$ & 3.35 & $\mathrm{ME}$ \\
\hline $\begin{array}{l}\text { Provides orientation on the policies and guidelines of the } \\
\text { scholarship and financial assistance of the state colleges. }\end{array}$ & 3.56 & $\mathrm{GE}$ & 3.38 & $\mathrm{ME}$ \\
\hline $\begin{array}{l}\text { Accepts and evaluates applications for scholarship and } \\
\text { financial assistance of the students. }\end{array}$ & 3.71 & $\mathrm{GE}$ & 3.41 & $\mathrm{ME}$ \\
\hline $\begin{array}{l}\text { Disseminates information of available scholarship slots } \\
\text { and financial assistance to students. }\end{array}$ & 3.57 & $\mathrm{GE}$ & 3.35 & $\mathrm{ME}$ \\
\hline $\begin{array}{l}\text { Educates students on the guidelines of varied scholarship } \\
\text { and financial assistantship. }\end{array}$ & 3.59 & $\mathrm{GE}$ & 3.4 & $\mathrm{ME}$ \\
\hline $\begin{array}{l}\text { Conducts screening for scholarship and financial } \\
\text { assistance applicants. }\end{array}$ & 3.66 & $\mathrm{GE}$ & 3.4 & $\mathrm{ME}$ \\
\hline Provides varied scholarship programs. & 3.66 & $\mathrm{GE}$ & 3.35 & $\mathrm{ME}$ \\
\hline $\begin{array}{l}\text { Implements system of selection of scholars for the } \\
\text { different scholarship programs. }\end{array}$ & 3.56 & $\mathrm{GE}$ & 3.41 & $\mathrm{ME}$ \\
\hline $\begin{array}{l}\text { Assists the scholars and grantees on the timely release of } \\
\text { their allowance /stipend. }\end{array}$ & 3.61 & $\mathrm{GE}$ & 3.36 & $\mathrm{ME}$ \\
\hline $\begin{array}{l}\text { Initiates enhancement classes for students with academic } \\
\text { problems. }\end{array}$ & 2.05 & $\mathrm{SE}$ & 2.87 & $\mathrm{ME}$ \\
\hline Composite Mean & $\mathbf{3 . 5 7}$ & $\mathrm{GE}$ & $\mathbf{3 . 2 9}$ & $\mathrm{ME}$ \\
\hline
\end{tabular}

\subsubsection{Scholarship and Financial Assistance}

For program implementers, periodical monitoring of academic performance of the scholars and grantees was performed to a great extent but enhancement classes for student with academic problems and provision of loans to financially incapable students were both delivered to a slight extent. Weighted mean values were $3.73,2.05$ and 2.01 respectively representing highest and lowest assessments. Summing up, the composite mean of 3.51 was an indication that the program implementers assessed scholarship and financial assistance was delivered to a great extent.

Student- leaders gave highest assessment on free tuition and allowance to academic scholars, athletes and performers cited to a great extent indicated by the weighted mean of 3.54. However, granting the provision of loans to financially incapable students was to a slight extent expressed in lowest weighted mean of 2.34. Summary of the assessments of student leaders was 3.29 indicating scholarship and financial assistantship was delivered to moderate extent. 
Table 9: Assessment on Food Services

\begin{tabular}{|c|c|c|c|c|}
\hline \multirow[t]{2}{*}{ Items } & \multicolumn{2}{|c|}{$\begin{array}{c}\text { Program } \\
\text { Implementers }\end{array}$} & \multicolumn{2}{|c|}{$\begin{array}{l}\text { Student } \\
\text { Leaders }\end{array}$} \\
\hline & WM & VI & WM & VI \\
\hline 1. Serves nutritious and affordable student meals & 3.273 & ME & 3.02 & ME \\
\hline $\begin{array}{l}\text { 2. Ensures that canteen operators have sanitary } \\
\text { permit to operate }\end{array}$ & 65 & GE & 3.23 & ME \\
\hline $\begin{array}{l}\text { 3. Ensures that food handlers wears uniform, gloves } \\
\text { and hairnet }\end{array}$ & 3.33 & ME & 3.05 & ME \\
\hline 4. Offers variety of food to choose from & 3.26 & ME & 3.02 & ME \\
\hline 5. Provides designated bushing and washing area & 3.122 .18 & ME & 2.98 & ME \\
\hline 6. Provides drinking fountain/faucet & 3.28 & SE & 2.05 & SE \\
\hline 7. Ensures cleanliness and sanitation of the canteen & & ME & 3.08 & ME \\
\hline 8. Installs covered trash cans for waste and left-over & 3.29 & $M F$ & 304 & MF \\
\hline 9. Provides proper ventilation and space to & 3.26 & $M \Gamma$ & 200 & \\
\hline $\begin{array}{l}\text { accommodate the students during eating hours } \\
\text { 10. Offers clean and comfortable place for serving }\end{array}$ & 3.37 & MIE & 3.02 & ME \\
\hline meals & & ME & 3.13 & ME \\
\hline 11. Offers reasonably priced food items & 3.29 & & & \\
\hline $\begin{array}{l}\text { 12. Ensures that canteen staff has the medical } \\
\text { certificate }\end{array}$ & 3.45 & ME & 2.92 & ME \\
\hline $\begin{array}{l}\text { 13. Ensures foods being served are free from } \\
\text { contamination }\end{array}$ & 3.47 & ME & 3.12 & ME \\
\hline $\begin{array}{l}\text { 14. Attends and accommodates meal orders of the } \\
\text { students promptly and courteously }\end{array}$ & & ME & 3.08 & ME \\
\hline 15. Sterilizes utensils for sanitation and hygiene & & ME & 3.10 & ME \\
\hline 16. Move & 3.36 & & & \\
\hline 17. Implements "CLEAN AS YOU GO" policy & 3.15 & ME & 3.04 & ME \\
\hline & 2.42 & ME & 2.88 & $\begin{array}{l}\mathrm{ME} \\
\mathrm{ME}\end{array}$ \\
\hline Composite Mean & 3.20 & ME & 2.99 & ME \\
\hline
\end{tabular}

\subsubsection{Food Services}

Both the program implementers and student leaders assessed that canteen operators had sanitary permit to operate cited complied with a moderate extent evidenced in the highest weighted means of 3.65 and 3.23. Both respondent groups assessed that provision for drinking fountain/ faucet was both affirmed by the program implementers and student leaders to a slight extent in weighted means of 2.18 and 2.05, respectively. The composite means of 3.20 and 2.99, respectively, described delivery of food services to a moderate extent. 
Table 10: Assessment on Health Services

\begin{tabular}{|l|l|l|l|l|}
\hline Items & \multicolumn{2}{|c|}{$\begin{array}{c}\text { Program } \\
\text { Implementers }\end{array}$} & \multicolumn{2}{c|}{$\begin{array}{c}\text { Ltudent } \\
\text { Leaders }\end{array}$} \\
\cline { 2 - 5 } & \multicolumn{1}{|c|}{ VM } & \multicolumn{1}{|c|}{ VM } & VI \\
\hline $\begin{array}{l}\text { Conducts programs and activities that promotes personal } \\
\text { hygiene and healthy lifestyles. }\end{array}$ & 3.48 & $\mathrm{ME}$ & 3.27 & $\mathrm{ME}$ \\
\hline Conducts immunization and vaccination. & 2.16 & $\mathrm{SE}$ & 2.03 & $\mathrm{SE}$ \\
\hline $\begin{array}{l}\text { Conducts physical and dental examination and health care } \\
\text { counseling. }\end{array}$ & 3.56 & $\mathrm{GE}$ & 3.13 & $\mathrm{ME}$ \\
\hline Treats minor injuries and illness of the students & 3.61 & $\mathrm{GE}$ & 3.32 & $\mathrm{ME}$ \\
\hline $\begin{array}{l}\text { Provides medicines to common illness including headaches, } \\
\text { body pain and colds. }\end{array}$ & 3.7 & $\mathrm{GE}$ & 3.39 & $\mathrm{ME}$ \\
\hline $\begin{array}{l}\text { Conducts health promotion programs and education to } \\
\text { ensure wellness of the students. }\end{array}$ & 3.51 & $\mathrm{GE}$ & 3.25 & $\mathrm{ME}$ \\
\hline Provide first aid information and education to students. & 3.51 & $\mathrm{GE}$ & 3.34 & $\mathrm{ME}$ \\
\hline Provides adequate medical and dental facilities. & 3.49 & $\mathrm{ME}$ & 3.21 & $\mathrm{ME}$ \\
\hline Provides mechanisms to address students health condition & 3.38 & $\mathrm{ME}$ & 3.14 & $\mathrm{ME}$ \\
\hline Updates student-medical records. & 3.31 & $\mathrm{ME}$ & 3.13 & $\mathrm{ME}$ \\
\hline Provides well-furnished medical-dental clinic. & 3.44 & $\mathrm{ME}$ & 3.17 & $\mathrm{ME}$ \\
\hline $\begin{array}{l}\text { Conducts medical examination to student participants in co- } \\
\text { curricular and curricular activities like training, seminars, } \\
\text { sports fest and off campus activities. }\end{array}$ & 3.62 & $\mathrm{GE}$ & 3.35 & $\mathrm{ME}$ \\
\hline Ensures confidentiality of clientele's health conditions. & 3.64 & $\mathrm{GE}$ & 3.23 & $\mathrm{ME}$ \\
\hline $\begin{array}{l}\text { Endeavors to provide up to date information relative to } \\
\text { medical and dental services. }\end{array}$ & 3.51 & $\mathrm{GE}$ & 3.18 & $\mathrm{ME}$ \\
\hline $\begin{array}{l}\text { Attends to emergencies and medical concerns of students } \\
\text { staying in dormitories. }\end{array}$ & 3.26 & $\mathrm{ME}$ & 3.1 & $\mathrm{ME}$ \\
\hline $\begin{array}{l}\text { Informs/parent/guardian on the health condition of their } \\
\text { child for proper medication. }\end{array}$ & 3.56 & $\mathrm{GE}$ & 3.15 & $\mathrm{ME}$ \\
\hline Monitors students condition with serious health problems & 3.41 & $\mathrm{ME}$ & 3.23 & $\mathrm{ME}$ \\
\hline Composite Mean & $\mathbf{3 . 4 2}$ & $\mathrm{ME}$ & $\mathbf{3 . 1 5}$ & $\mathrm{ME}$ \\
\hline
\end{tabular}

\subsubsection{Health Services}

The program implementers assessed to provision of medicine to common illnesses including was to a great extent and had a weighted mean of 3.70 but which was assessed by the student leaders as provided to a moderate extent with weighted mean of 3.39. Moreover, the conduct of immunization and vaccination was both assessed by the program implementers and student leader as done to a slight extent expressed in weighted means of 2.16 and 2.03, respectively. Composite means of 3.42 and 3.15 were both showed moderate implementation of health services. 
Table 11: Assessment on Library Services

\begin{tabular}{|l|l|l|l|l|}
\hline \multirow{2}{*}{ Items } & \multicolumn{2}{|c|}{$\begin{array}{c}\text { Program } \\
\text { Implementers }\end{array}$} & \multicolumn{2}{|c|}{$\begin{array}{c}\text { Student } \\
\text { Leaders }\end{array}$} \\
\cline { 2 - 6 } & WM & \multicolumn{1}{|c|}{ VI } & WM & VI \\
\hline $\begin{array}{l}\text { Conducts orientation to the students on the policies } \\
\text { and services of the library. }\end{array}$ & 3.74 & GE & 3.42 & ME \\
\hline $\begin{array}{l}\text { Provide electronic research materials and online } \\
\text { resources }\end{array}$ & 3.58 & GE & 3.29 & ME \\
\hline $\begin{array}{l}\text { Provides equipment and facilities ie., printer and } \\
\text { photocopier for students research purposes. }\end{array}$ & 3.55 & GE & 3.31 & ME \\
\hline Provides non print materials like CD's, \& DVDs. & 2.14 & SE & 2.29 & SE \\
\hline $\begin{array}{l}\text { Provides periodicals such as journals, newspaper and } \\
\text { magazines. }\end{array}$ & 3.68 & GE & 3.41 & ME \\
\hline $\begin{array}{l}\text { Has available strong Wi-Fi connection and internet } \\
\text { access in computers. }\end{array}$ & 2.23 & SE & 2.42 & SE \\
\hline Provides spacious reading and study areas & 3.68 & GE & 3.37 & ME \\
\hline $\begin{array}{l}\text { Labels and arranges books for the convenient use of } \\
\text { the students. }\end{array}$ & 3.68 & GE & 3.30 & ME \\
\hline $\begin{array}{l}\text { Provides OPAC (Online Public Access } \\
\text { Catalog) }\end{array}$ & 3.58 & GE & 3.28 & ME \\
\hline Provides e-library for easy access & 3.45 & ME & 3.26 & ME \\
\hline $\begin{array}{l}\text { Has sufficient number of computer units for researches } \\
\text { and typing/ encoding }\end{array}$ & 2.25 & SE & 2.47 & SE \\
\hline Provides adequate service hours for clientele & 3.53 & GE & 3.25 & ME \\
\hline $\begin{array}{l}\text { Shares knowledge and expertise to sufficiently help } \\
\text { the student -researchers }\end{array}$ & 3.36 & ME & 3.22 & ME \\
\hline $\begin{array}{l}\text { Provides sufficient collection of books (including } \\
\text { eBooks) needed by the students - researchers }\end{array}$ & 3.32 & ME & 3.14 & ME \\
\hline $\begin{array}{l}\text { Secures safety of researchers' belongings by providing } \\
\text { luggage/staff counter }\end{array}$ & 3.51 & GE & 3.30 & ME \\
\hline Composite Mean & $\mathbf{3 . 2 9}$ & ME & $\mathbf{3 . 1 2}$ & ME \\
\hline
\end{tabular}

\subsubsection{Library Services}

Both respondent groups assessed the conduct of orientation to the students on the policies and services of the library was to great extent which obtained the highest mean scores of 3.74 and 3.42 done to a moderate extent, respectively. Moreover, both assessed print materials was to a slight extent with weighted means of 2.14 for program implementers and 2.29 for the student leaders. Results revealed that as per respective assessment of program implementers, the composite mean obtained was 3.29 which was higher than the assessment of the student leaders with composite mean value of 3.12 implying that library services were delivered to a moderate extent. 
Table 12: Assessment of on Student Housing Services

\begin{tabular}{|l|l|l|l|l|}
\hline \multirow{2}{*}{ Items } & \multicolumn{2}{|c|}{$\begin{array}{c}\text { Program } \\
\text { Implementers }\end{array}$} & $\begin{array}{l}\text { Student } \\
\text { Leaders }\end{array}$ \\
\cline { 2 - 5 } & \multicolumn{1}{|c|}{ WM } & VI & MEAN & \multicolumn{1}{|c|}{ VI } \\
\hline $\begin{array}{l}\text { Provides list of accredited student boarding houses } \\
\text { and dormitories }\end{array}$ & 2.52 & ME & 2.59 & ME \\
\hline $\begin{array}{l}\text { Coordinates with the private boarding houses } \\
\text { operators to ensure the welfare of the students }\end{array}$ & 2.52 & ME & 2.51 & ME \\
\hline Provides dormitories inside the campus & 2.52 & ME & 2.68 & ME \\
\hline $\begin{array}{l}\text { Designates committed and competent dormitory-in- } \\
\text { charge/staff }\end{array}$ & 2.49 & SE & 2.61 & ME \\
\hline Conducts dormitory orientation services & 2.52 & ME & 2.58 & ME \\
\hline Enforces dormitory rules and regulations & 2.60 & ME & 2.62 & ME \\
\hline Offers affordable dormitory fees & 2.62 & ME & 2.66 & ME \\
\hline $\begin{array}{l}\text { Provides beds, chairs, study tables and locker for } \\
\text { storage }\end{array}$ & 2.42 & SE & 2.55 & ME \\
\hline Provides separate toilets and bathrooms & 2.44 & SE & 2.58 & ME \\
\hline Provides separate rooms for men and women & 2.67 & ME & 2.71 & ME \\
\hline Provides separate study room & 2.34 & SE & 2.36 & SE \\
\hline $\begin{array}{l}\text { Ensures that dormitories policy and guidelines are } \\
\text { posted for the information of the dormers. }\end{array}$ & 2.62 & ME & 2.47 & SE \\
\hline $\begin{array}{l}\text { Monitors incoming and outgoing visitors and } \\
\text { dormers }\end{array}$ & 2.40 & SE & 2.44 & SE \\
\hline Provides well ventilated and lighted dormitories & 2.45 & SE & 2.39 & SE \\
\hline $\begin{array}{l}\text { Monitors and evaluate the condition of dormitories } \\
\text { regularly }\end{array}$ & 2.39 & SE & 2.48 & SE \\
\hline Provides supply of potable drinking water & 2.44 & SE & 2.52 & ME \\
\hline Enforces sanctions for dormers misconduct & 2.38 & SE & 2.49 & SE \\
\hline Composite Mean & $\mathbf{2 . 4 9}$ & SE & $\mathbf{2 . 5 4}$ & ME \\
\hline
\end{tabular}

\subsubsection{Student Housing}

Separate rooms for men and women was perceived by the program implementers and student leaders to a moderate extent reflected in weighted means of 2.67 and 2.71, respectively. While separate study room was provided to a slight extent concurred by the two respondent groups expressed in weighted means of 2.34 and 2.36, respectively. Program implementers assessed housing services were delivered to a slight extent indicated with a composite mean of 2.49 while the student leaders assessed student housing was offered to a moderate extent justified in composite mean of 2.54 . 


\subsection{Differences between the Assessments on the Student Services of the Program Implementers and Student Leaders}

Table 13: Comparison of Assessment made by Implementers and Student Leaders on the Delivery of Student Services

\begin{tabular}{|l|l|l|l|}
\hline Student Services & $\begin{array}{l}\text { Mean } \\
\text { Difference }\end{array}$ & $\begin{array}{l}\text { Standard } \\
\text { Error }\end{array}$ & $\begin{array}{l}\text { Computed } \\
\text { t-value }\end{array}$ \\
\hline Admission Services & 0.28 & 0.0641 & $4.9694^{* *}$ \\
\hline Guidance Services & 0.22 & 0.0717 & $3.1126^{* *}$ \\
\hline Scholarship and Financial Assistance & 0.21 & 0.0682 & $3.0160^{* *}$ \\
\hline Food Services & 0.23 & 0.0749 & $3.3322^{* *}$ \\
\hline Health Services & 0.28 & 0.0678 & $3.9504^{* *}$ \\
\hline Library Services & 0.24 & 0.067 & $3.6706^{* *}$ \\
\hline Student Housing Services & 0.05 & 0.1266 & $0.3723 \mathrm{~ns}$ \\
\hline
\end{tabular}

**- highly significant ns- not significant

critical t-value at $\alpha=5 \%: 1.96$

There were significant differences in the assessments between the program implementers and student leaders with respect to the delivery of admission, guidance, scholarship and financial, food, health, and library services justified in computed t-value ranging from 3.016 to 4.9694 which were all higher than the critical value at 5\% level of significance equal to 1.9659 .

However, no significant difference was noted in assessments on housing services registered in the computed t-value of 0.3723 which was lesser than the critical value of 1.9659 which indicates that the assessments made by the two respondent groups are not significantly different from each other.

\section{Innovative Practices in Student Services Delivery}

Results of the data gathered from the two respondents groups revealed that the innovative practices for quality student services in their respective institutions were on install of CCTV camera is in some areas of the campus for surveillance and security purposes ; provision of separate counseling, testing, and conference rooms to ensure confidentiality of the student records and proceedings; fully air-conditioned school libraries, lying in clinic / infirmary cited to be available for patients' short confinement; and installation of security gate in the library to prevent theft and loss of its collection. These innovative practices, however, were delivered to a moderate extent.

\section{The proposed Management Plan of Quality Student Services Delivery}

The prepared management plan for quality student services delivery was conceptualized based on the areas of concern assessed to be needing improvement as voiced out by the student leaders and the program implementers. This plan is meant to help enhance and effectively implement student services. As designed, the management plan sets objectives, strategic measures/ activities and expected outcome for each area of concern. 


\section{Conclusions and Recommendations}

Results of the study revealed that majority of the program implementers are middle aged, female outnumbered the males. Most are either with units / graduates in the Graduate School, majority are in the service from 10 years and below and attended an average of 5 related training and seminars annually. The implementation of admission services, guidance and counseling services, scholarship and financial assistance have met the student leaders' satisfaction. On the other hand, health services, food services and library services must be prioritized for further enhancement of its services. Additionally, student housing services do not meet the existing needs and demands of the dormers as evident to its very low assessment which calls to improve the quality of services. Program implementers differ in their assessment on student services in terms of admission, guidance, scholarship and financial assistance, food, health and library services but they have the same assessment with regard to student housing. High - technological practices like downloadable application forms, electronic queuing system and paperless clearance system were not integrated in innovative practices in student services delivery.

Based on the findings and conclusions, it is recommended that student housing facilities may be improved by providing adequate furniture, fixtures and separate bathroom and comfort room for the convenience of the dormers and intensive monitoring of dorm-in-charge is highly recommended. The administrators may allocate fund for the procurement of highly technological equipment / device for effective delivery of student services and plan for One Stop Shop Services Model. The Office of Student Affairs may review and implement/ adopt the proposed management plan for quality student services delivery.

\section{References}

[1] Corey, G. (2016). Theory and Practice of Counseling and Psychotheraphy (8thEdition) Belmont Brooke Cole.

[2] Santos, Z. et.al. (2014). Principles and Practices of Guidance and counseling: Theory and Practice. First edition.

[3] Babayben - On, Lily B. (2010). "The level of Satisfaction with Services of the Davao Doctor's College: Basis for Development Plan. Unpublished Dissertation."

[4] Bardell J. and Russel A. (2012). "Innovative Delivery of Student Services." University of Exeter.

[5] Bola, Nymata and Ojibara, L (2011). "Assessment of Stakeholder's Perceptions on the Provision and the Management of Academic and Welfare Services in Nigerian Colleges of Education".

[6] Bunda, Maria Gina Cruz. (2011). "Canteen Management of Selected Schools in Pasig Diocesan System (PADSS): An Assessment. University of Regina Carmille, City of Malolos. Calamba: An enrollment trend analysis." MBA Thesis. Laguna College of Business and Arts. Calamba City.

[7] McCaig, M. (2013) "Importance and Effectiveness of Student Health Services at a South Texas University". Unpublished Dissertation

[8] Soares, J. A. (2012). The future of college admissions: Discussion. Educational Psychologist, 47(1), 66-70.

*Corresponding author.

E-mail address: evelynleynes02@gmail.com 